\title{
Viability of $L$. casei during fermentation in soymilk and freeze-dried soymilk; effect of cryoprotectant, rehydration and storage temperature
}

\author{
Lela Acevska1, Kristina Mladenovska², Tanja Petreska Ivanovska1, Maja Jurhar Pavlova³, \\ Milena Petrovska3 ${ }^{3}$ Angela Delova ${ }^{4}$, Lidija Petrusevska Tozi ${ }^{1 *}$ \\ ${ }^{1}$ Department of Food and Nutrition and ${ }^{2}$ Department of Biopharmacy, Faculty of Pharmacy, Vodnjanska 17, 1000, Skopje; \\ ${ }^{3}$ Institute of Microbiology and Parasitology, Faculty of Medicine, Vodnjanska 19, 1000 Skopje, \\ University "Ss. Cyril and Methodious", Skopje, Macedonia, \\ ${ }^{4}$ Health Care Institute, Partizanska bb, 7000 Bitola, Macedonia
}

Received September 2005, accepted December 2005

\begin{abstract}
The aim of the work was to investigate the behaviour of $L$. casei and the effect of sorbitol on its viability during fermentation in soymilk drink. Values for $\mathrm{pH}$, ranging from 6.82 to 3.42 in the soymilk drink without sorbitol and from 6.74 to 3.41 in the drink with sorbitol were noted during $72 \mathrm{~h}$ of fermentation at $25^{\circ} \mathrm{C}$. The corresponding values for titratable acidity ranged from $0.071 \%$ to $0.758 \%$ and from $0.073 \%$ to $0.761 \%$, respectively. Soymilk was found to support the growth of $L$. casei with improvement in viability for 0.24 $\log$ at the end of fermentation when sorbitol was added. Survival of L. casei and the effectiveness of sorbitol in improving viability during freeze-drying, subsequent rehydration and during a 5-week period of storage under different temperatures were also investigated. After freeze-drying, L. casei exhibited a survival percent of approximately $46 \%$. Sorbitol improved the viability of $L$. casei by 0.51 log immediately after freeze-drying and by $1.30 \mathrm{log}$ and $0.47 \mathrm{log}$ during five weeks of storage at $25^{\circ} \mathrm{C}$ and $4^{\circ} \mathrm{C}$, respectively. Further study revealed that the freeze-dried fermented soymilk rehydrated at $45^{\circ} \mathrm{C}$ was optimum for the recovery of $L$. casei with improvement in recovery for $0.68 \log$ when sorbitol was added. A higher percent of survival was noted when the dried soymilk was stored at $4^{\circ} \mathrm{C}$ than at $25^{\circ} \mathrm{C}$ with improved viability at the end of 5 weeks storage for approximately 6 log for drinks with and without sorbitol. Fermented dried soymilk with sorbitol afforded significant tolerance of $L$. casei to acid stress. Generally, a stable probiotic diary product was prepared in which the concentration of $L$. casei remained above therapeutic level of $10^{7} \mathrm{cfu} / \mathrm{ml}$.
\end{abstract}

Keywords: L. casei, fermented soymilk, freeze-drying, sorbitol, viability

\section{Introduction}

Soybean is one of the most important oilseeds in the world. Besides the extra protein and fibre, the biggest benefit in soybean are the isoflavones connected to a whole host of health issues, the most important being prevention of many cancers, heart diseases, osteoporosis and more (1-5). In addition, soybean contains powerful antioxidants that help fight disease and aging, thus strengthening the immune system (6-7). Soy fibre, in a healthy diet, may help control diabetes

*Lidija Petrusevska Tozi

e-mail: lito@ff.ukim.edu.mk

tel: 0038923126 032; fax: 0038923123054 by making the body more sensitive to insulin in the bloodstream, while slowing the release of glucose into the bloodstream to a more manageable rate (8). Also, soybean could be effective in the protection of neuropathy induced by diabetes mellitus (9). Soy's ability to lower LDL cholesterol in the blood (10) also helps to prevent kidney damage (11-12).

However, the oligosaccharide constituents in soybean, such as raffinose and stachyose are not digested by human beings and thus may cause flatulence. This along with the disagreeable beany flavour has limited the consumption of soybean as the raw food material. In order to increase both acceptability and nutritional value, fermentation of soybean products with lactic acid bacteria has been studied extensively to develop more digestible and palatable foods 
such as fermented soybean cheese, sour milk beverage and soybean yogurt (13-15). Soymilk as a water extract of soybean has long been a popular alternative for people who are unable to drink cow's milk (usually due to lactose intolerance). But rather than drink soymilk because you have to, more and more people are deliberately choosing soymilk because of the added health benefits.

Lactic acid has been widely used as an acidulant and many reports have shown the usefulness of lactic acid bacteria as probiotics for humans and animals (16-19). Probiotic culture, known to be (+)-lactic acid producer exhibiting promising therapeutic potential, is Lactobacillus casei. The action of this probiotic on intestinal flora results in vital benefits, including prevention and treatment of gastrointestinal disorders, such as colon irritation, constipation, paediatric and travellers' diarrhoea (20-22), ulcerative colitis and Crohn's disease (23-24). Other important properties include liver improvement function (25), prevention of cancer and cardiovascular diseases (anticholesterolaemic effect) (26), antimicrobial activity (27-28) and reduction of food intolerance (29). The beneficial effect is proposed to be due, at least in part, to interference with the innate immune system and possibly the orientation of adaptive immunity (30).

The homofermentative $L$. casei is acidotolerant with an optimum $\mathrm{pH}$ of 5.5 and is relatively insensitive to product inhibition by lactic acid (31). In order to exert any beneficial health effect, the concentration in a product that serves as a delivery system needs to be in a therapeutic level ranging from $10^{6}$ to over $10^{7} \mathrm{cfu} / \mathrm{ml}$ or gram product (32-34). The main obstacle for achieving and maintaining required levels is the strain-dependence and poor survival due to increased acidity and oxygen tension (35).

Probiotics usually have limited shelf-life in conventional yoghurt as well as in the product itself. Freeze-drying is a process that not only preserves the yoghurt, but also helps to maintain a sufficient quantity of viable probiotics. Previous research (36) has found that certain $L$. casei strains are able to survive the freeze drying process with the percent of survival ranging from $41 \%$ to $75 \%$ depending significantly on the bacterial strain. During the processing and storage of freeze-dried yoghurt, oxygen content, high temperature, low $\mathrm{pH}$, water activity and elevated solution concentration may all affect the viability of probiotic organisms (36-37). Compatible cryoprotectants may be added to media or into the yoghurt mix prior to fermentation to assists in the adaptation of probiotic to the environment and maintain the viability during freeze-drying (38-40). As compatible cryoprotectants accumulate within the cells, the osmotic difference with their external environment is reduced. The extent to which cryoprotection is provided by any given cryoprotectant varies between cultures (39; 41-45).
Considering the above-mentioned, the behaviour of L. casei in soymilk drink during fermentation was studied and the effect of sorbitol as a sugar derivative present in the growth medium was evaluated. In this study, an attempt was made to dehydrate fermented soymilk with freeze-drying, which is commonly employed in food industry. Survival of $L$. casei during the drying process and the effect of sorbitol in preserving probiotic's viability were investigated. In addition, chemical properties and the viability of $L$. casei in the dried soymilk after rehydration, acid challenge and storage under different temperature conditions during 5 weeks were compared.

\section{Materials and methods}

\subsection{Microorganism and chemicals}

L. casei (FD-DVE/L. casei-01-nu-trish was kindly provided by Chr. Hansen (Copenhagen, Denmark). For fermented milk preparation whole sterile pasteurized soymilk (SoVita, Vitalia, Skopje, Macedonia) was used. As a cryoprotectant, sorbitol was purchased from Merck KGaA (Darmstadt, Germany). For bacterial enumeration, MRS Agar (CM0361, de man, Rogosa, Sharpe, Oxoid LTD, Basingstoke, Hampshire, England) and peptone water (Oxoid LTD, Basingstoke, Hampshire, England) were used.

\subsection{Preparation of fermented probiotic soymilk}

In this study, a strain of $L$. casei was used as a single culture for production of fermented soymilk. For the preparation, whole sterile soymilk inoculated with $L$. casei $(0.05 \mathrm{~g} / \mathrm{L})$ was used. Samples with and without cryoprotectant were prepared. As a cryoprotectant, sorbitol was used in concentration of $25 \mathrm{~g} / \mathrm{L}$. Sorbitol was added to the soymilk during phase of fermentation. According to the preliminary results related to the microbial and chemical characterisation, which were in accordance with those of probiotic producer, inoculated soymilk fermented for 3 days without shaking at temperature of $25^{\circ} \mathrm{C}$ until a $\mathrm{pH}$ of 3.42 was reached in both samples with and without sorbitol. The initial population of L. casei was $2.98 \times 10^{8} \mathrm{cfu} / \mathrm{ml}$ and at the end of fermentation the maximum population of $9.7 \times 10^{19} \mathrm{cfu} / \mathrm{ml}$ was obtained in the samples without sorbitol, while in the samples with sorbitol, the corresponding values were $2.7 \times 10^{8}$ and $1.68 \times 10^{20} \mathrm{cfu} / \mathrm{ml}$, respectively.

\subsection{Drying of fermented probiotic soymilk}

In this study, the fermented probiotic soymilk was subjected to drying with freeze-drying. The samples were stored in tightly sealed sterile bottles and frozen at $-20^{\circ} \mathrm{C}$. Then, frozen samples were than lyophilized with a freeze-dryer (Freeze Dry System, Labconco, USA) at a condenser temperature of $-45^{\circ} \mathrm{C}$ and $0.180 \mathrm{mBar}$ vacuum for about $50 \mathrm{~h}$ (13-14). 


\subsection{Storage of the dried fermented probiotic soymilk}

Each of the freeze-dried products of fermented probiotic soymilk (10 g) was placed in a $100 \mathrm{ml}$ glass bottle and vacuum sealed before storage. Then, were stored at either $25^{\circ} \mathrm{C}$ or $4^{\circ} \mathrm{C}$ for a period of 5 weeks. The chemical characterization, viability of probiotic organism and moisture content of the samples were measured at predetermined time intervals. Moisture content of the samples was determined according to the AOAC method (46).

\subsection{Rehydration study}

When the rehydration phase was performed, the dried fermented samples were mixed with peptone water $(0.1 \mathrm{~g} / \mathrm{ml}$; Peptone water, Oxoid LTD, Hampshire, England), which was pretempered at $25^{\circ} \mathrm{C}, 45^{\circ} \mathrm{C}$ and $/$ or $90^{\circ} \mathrm{C}$. The constituted samples were then serially diluted with peptone water and spread-plated on the appropriate medium to enumerate the test organisms.

\subsection{Acid challenge}

One gram of fermented whole and freeze-dried probiotic soymilk was homogenized in $9.0 \mathrm{ml} 0.025 \mathrm{~N} \mathrm{HCl}$, leading to final $\mathrm{pH} 2.0$ prior to a $60 \mathrm{~min}$ incubation. After $60 \mathrm{~min}$ of acid challenge, samples were quickly diluted in peptone water and surviving cells counted (47). Acid challenge test was applied to samples with and without sorbitol, and for the freeze dried samples the test was applied after 1 week storage at $4^{\circ} \mathrm{C}$ and $25^{\circ} \mathrm{C}$, respectively.

\subsection{Chemical analyses}

\subsubsection{Titratable acidity (TA) and $p H$}

TA was determined using the method (number 16.023) of AOAC (46) by titration with $0.01 \mathrm{~N} \mathrm{NaOH}$ solution and expressed as percent lactic acid, while the $\mathrm{pH}$ of the samples was measured using a pH meter (Jenway ltd., Felsted, UK).

\subsection{Microbial analyses}

\subsubsection{Enumeration of probiotic L. casei}

For the enumeration of $L$. casei, de man Rogosa Sharpe (MRS) agar, as described by Otieno et al. (2), Minelli et al. (15) and Ha et al. (48) was used.

When the enumeration of bacteria was performed, $1 \mathrm{~g}$ of the dried fermented soymilk or $1 \mathrm{ml}$ of the fermented soymilk sample was mixed with $9.0 \mathrm{ml}$ of peptone water, vortexed for $15 \mathrm{~s}$ and serially diluted with peptone water. Serially diluted sample $(0.1 \mathrm{ml})$ was spread-plated onto the appropriate medium mentioned above. After $72 \mathrm{~h}$ of incubation at $37^{\circ} \mathrm{C}$, the colonies that appeared on the plates were counted (cell counter, Esko, Yugo Lek, Belgrade, Serbia) and the cfu per ml was calculated.

\subsection{Statistical analysis}

The mean values and the standard deviation were calculated from the data obtained with triplicate trials. These data were compared with the Student,s $t$-test and two-factorial analysis of variance with a confidence interval of $95 \%$ (49).

\section{Results and discussion}

\subsection{Moisture content of the fermented soymilk after drying}

Water content is an important parameter for the stability of dried cultures. In general, microorganisms survive better in low-water activity. However, over drying may diminish the viability and stability of microorganisms (50). Besides, it is reported that the optimum residual moisture content varies with the composition of the fluid in which the microorganisms are dried, with the storage atmosphere and with the species of organisms (51). The moisture content in the samples of freeze-dried fermented probiotic soymilk, with and without sorbitol, was determined immediately after freeze-drying and it was approximately 5\%. No significant difference in moisture content was observed among the samples with and without sorbitol. According to literature data (51), freeze-dried samples may be considered as stable.

\subsection{Changes in $\mathrm{pH}$ and titratable acidity in soymilk during the fermentation and storage of freeze-dried fermented soymilk with L. casei}

In general, $\mathrm{pH}$ value determines the processes, such as milk fermentation, enzyme activity, bacterial growth and it is an indicator for the taste of the product. The growth of lactobacilli is usually associated with production of acids, such as lactic and acetic acid. In order to detect measurable increase in acidity, the number of microorganism has to increase for several millions per millilitre. During fermentation in the food product, the content of acids increases, that of carbohydrates decreases and consequently $\mathrm{pH}$ value too. This process of acidification is one of the most desirable side effects of bacterial growth. $\mathrm{pH}$ value may decrease below 4.0, which is low enough to inhibit the bacterial growth of many other microorganisms, including most of the human pathogens, by which the storage time of the product is prolonged. Acidity may change the texture of the food product due to the protein precipitation, while biochemical changes resulting from the bacterial growth may change the odour and taste of the product. Fermentation is self-limited due to the sensitivity of lactobacilli to low $\mathrm{pH}$.

During the study, changes in acidity have been followed in non-freeze-dried probiotic samples of whole soymilk with and without sorbitol and in freeze-dried samples stored at $25^{\circ} \mathrm{C}$ and $4^{\circ} \mathrm{C}$ during 5 weeks. $\mathrm{pH}$ value for the whole soymilk in the beginning of the study (without probiotic 
and cryoprotectant) was 6.95 , while for titratable acidity, $0.061 \%$ of lactic acid was determined. During the fermentation (3 days), $\mathrm{pH}$ values in non-freeze-dried samples without sorbitol decreased from 6.82 to 3.42 in milk stored at $25^{\circ} \mathrm{C}$ and to 6.28 in milk stored at $4{ }^{\circ} \mathrm{C}$ (fig. 1). In the samples in which sorbitol was added during the fermentation phase, the $\mathrm{pH}$ values ranged from 6.74 to 3.41 and to 5.74 (Fig. 1), accordingly. Non-significant difference in the acidity among samples with and without sorbitol at the beginning of the study can be explained by the presence of sorbitol. Namely, the $\mathrm{pH}$ of whole soymilk without sorbitol was 6.95, and for samples with sorbitol $\mathrm{pH}$ of 6.87 was measured.

In the next step of the study, the acidity of the samples stored at $25^{\circ} \mathrm{C}$ did not change significantly $(\mathrm{pH} 3.49$ in the samples with probiotic only and $\mathrm{pH} 3.16$ in the samples with probiotic and sorbitol after 5 weeks; Fig. 1). These data, along with the most significant changes in $\mathrm{pH}$ during 3 days, sensory properties and microbial growth (presented bellow) have pointed to the optimal period of fermentation and freeze-drying by that, also. It is important to emphasize that at the time of freezing, the samples possessed acceptable sensory properties and for freeze-drying, samples fermented at $25^{\circ} \mathrm{C}$ were used due to the faster and quantitatively more significant bacterial growth (presented bellow).

Acidity, expressed with $\mathrm{pH}$ values was determined in freeze-dried samples also immediately after freeze-drying and during the examined period of 5 weeks. It ranged from 3.25 to 3.44 in samples with probiotic stored at $25^{\circ} \mathrm{C}$ (Fig. 2) and from 3.25 to 2.74 in samples stored at $4^{\circ} \mathrm{C}$ (Fig. 3). In the samples with sorbitol, these values ranged from 3.21 to 3.32 at $25^{\circ} \mathrm{C}$ (Fig. 2) and from 3.21 to 2.68 at $4^{\circ} \mathrm{C}$ (Fig. 3). These data, besides water content, havered point also to the product with acceptable stability. In all freeze-dried samples sensory properties of the fermented soymilk were preserved, including light yellow colour and pleasant odour and taste.

Considering the changes in $\mathrm{pH}$ value in freeze-dried soymilk samples with $L$. casei, with and without sorbitol, stored at $25^{\circ} \mathrm{C}$, decrease in $\mathrm{pH}$ was observed during the first 2 weeks from 3.25 to 3.03 in samples without sorbitol and from 3.21 to 3.02 in samples with sorbitol (Fig. 2). Afterwards, the pH values began to increase to 3.44 and 3.32, respectively, showing decrease in survival rate, which was further confirmed by microbial studies (presented bellow). In all freeze-dried samples, with and without sorbitol, stored at $4^{\circ} \mathrm{C}$, the acidity was continuously decreasing during the whole period of the study, indicating higher survival rate of $L$. casei when product was stored at $4^{\circ} \mathrm{C}$, which was also confirmed by the microbial studies (Fig. 3). In addition, comparison of pH values between the samples with and without sorbitol has shown higher viability when sorbitol is added during the fermentation, which was more pronounced in the samples stored at $4^{\circ} \mathrm{C}$.

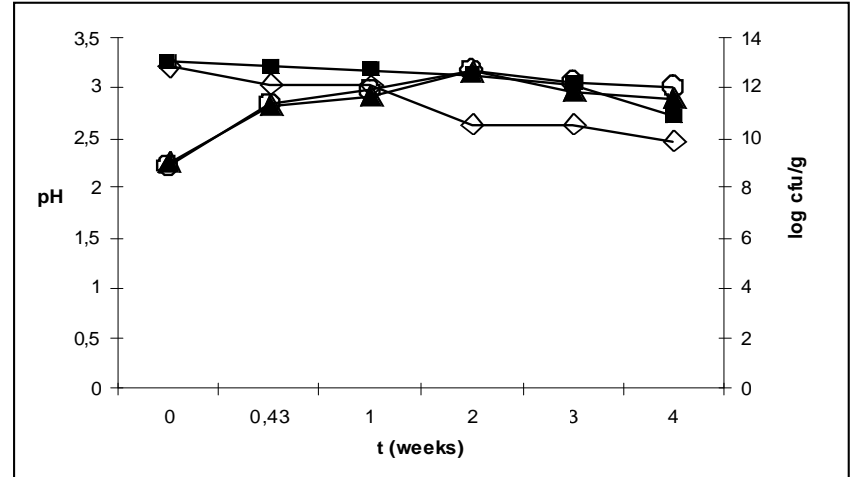

Fig. 1. Changes of pH in soymilk during the growth of L. casei in wohole fermented soymilk; samples without ( $\mathbf{\square})$ and with $(\diamond)$ sorbiol stored at $25^{\circ} \mathrm{C}$; samples without $(\mathbf{\Delta})$ and with $(\bigcirc)$ sorbiol stored at $4^{0} \mathrm{C}$.

As was previously mentioned, the acidity was determined by the values of TA, also. In general, decrease in $\mathrm{pH}$ was followed by increase in TA. TA in non-freeze-dried soymilk without sorbitol stored at $25^{\circ} \mathrm{C}$ during 5 weeks ranged from 0.071 to $0.857 \%$ vs. TA of the same sample stored at $4^{\circ} \mathrm{C}$, where TA ranged from 0.071 to $0.504 \%$ (Fig. 4). Considering the samples with sorbitol, the values for TA ranged from 0.073 to $0.945 \%$ and to $0.738 \%$, respectively (Fig. 4). In addition, the whole soymilk without probiotic and sorbitol had TA of $0.061 \%$, while for samples with sorbitol only, TA of $0.070 \%$ was determined. During the fermentation period, TA values increased to $0.758 \%$ and $0.137 \%$ in the samples without sorbitol stored at $25^{\circ} \mathrm{C}$ and $4^{\circ} \mathrm{C}$, respectively, while for the samples with sorbitol, the corresponding values were $0.761 \%$ and $0.246 \%$, respectively.

When freeze-dried samples analyzed, the values for TA in the samples without sorbitol ranged from $0.612 \%$ immediately after freeze-drying to $0.630 \%$ when stored at $25^{\circ} \mathrm{C}$ (Fig. 5) and to 0.759 when stored at $4^{\circ} \mathrm{C}$ (Fig. 6). From these data, one can notice that when product was stored at $4^{\circ} \mathrm{C}$, higher percent of lactic acid is obtained, pointing to the higher viability of $L$. casei at this storage temperature, which was confirmed by the microbial growth also (Fig. 5-6). These differences can be explained by the phases of microbial growth i.e. the factors influencing the microbial growth, including the medium and the temperature, for which the comment is given further in this paper. The same observations were confirmed for the values of TA obtained in the samples with sorbitol in which TA ranged from $0.846 \%$ to 0.792 and to $1.094 \%$ when stored at $25^{\circ} \mathrm{C}$ (Fig. 5) and $4^{\circ} \mathrm{C}$ (Fig. 6), respectively.

When comparing the values for TA between samples with and without sorbitol at constant storage temperature, one can observe that at $25^{\circ} \mathrm{C}$, the values for TA were continuously increasing and they were higher in samples with sorbitol during the entire examined period. The difference was more significant $(\mathrm{p}<0.05)$ when samples were stored at $4^{\circ} \mathrm{C}$. 


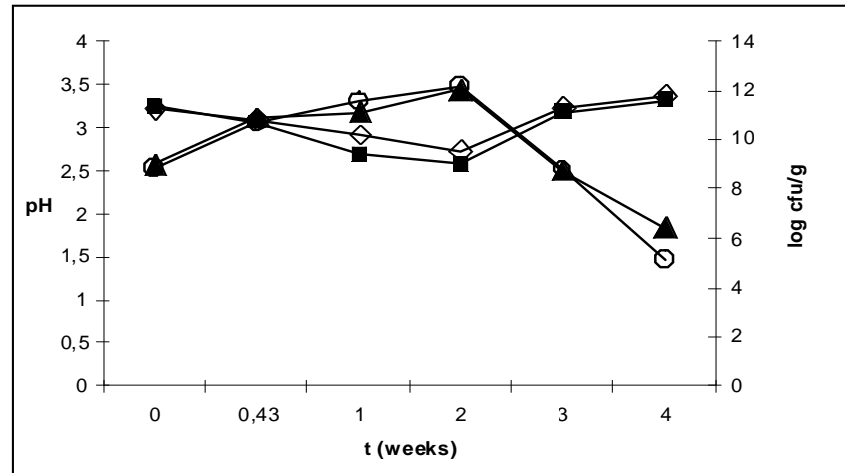

Fig. 2. pH $(\mathbf{\square}, \diamond)$ and growth $(\boldsymbol{\Lambda}, \bigcirc)$ of L. casei in freeze-dried fermented soymilk stored at $25^{\circ} \mathrm{C} ;(\mathbf{\square}, \mathbf{\Lambda})$ samples without sorbitol; $(\diamond, \bigcirc)$ samples with sorbitol.

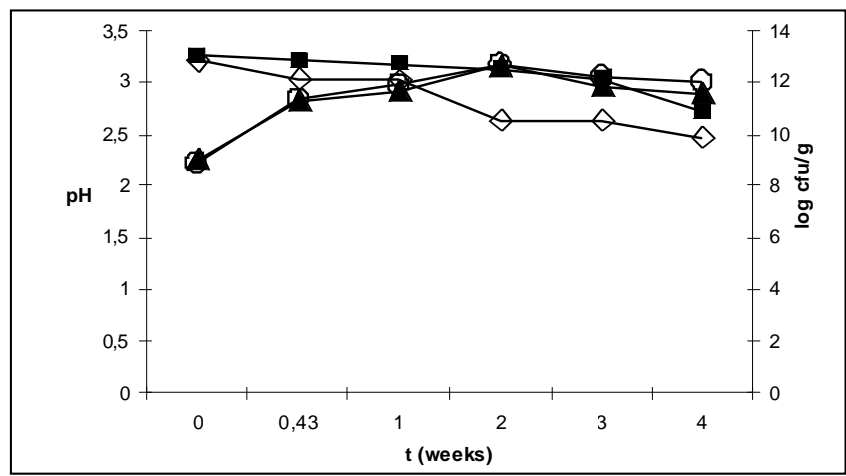

Fig. 3. pH $(\mathbf{\square}, \diamond)$ and growth $(\boldsymbol{\Delta}, \bigcirc)$ of L. casei in freeze-dried fermented soymilk stored at $4^{0} \mathrm{C} ;(\boldsymbol{\square}, \boldsymbol{\Delta})$

samples without sorbitol; $(\vee, \circ)$ samples with sorbitol.

\subsection{Microbial analyses}

3.3.1. Survival of $L$. casei after freeze-drying and during storage in the fermented dried soymilk

The growth and survival of $L$. casei in the fermented soymilk was monitored during the fermentation, freezedrying and storage at different temperatures. The presence of $L$. casei in the medium was confirmed microscopically (Nikon, E-800, Japan) and by culture preparation (Fig. 7).

Initially, the population of $L$. casei in the soymilk after $1 \mathrm{~h}$ of inoculation and during the three-day fermentation in the samples with and without sorbitol was determined. Also, the initial population of $L$. casei immediately after freezedrying was determined in the samples with and without sorbitol. In the samples without sorbitol stored at $25^{\circ} \mathrm{C}$, the number of cfu/ml was $2.98 \times 10^{8}$ in the beginning of the fermentation and it increased up to $9.7 \times 10^{19} \mathrm{cfu} / \mathrm{ml}$ by the end of the fermentation (the $3^{\text {rd }}$ day). In the samples with sorbitol fermented at the same temperature, the number of cfu/ml was $2.7 \times 10^{8}$ and $1.68 \times 10^{20} \mathrm{cfu} / \mathrm{ml}$, respectively. The number of cfu/ml determined immediately after freeze -drying did not differ significantly when comparing freezedried samples with and without sorbitol. Thus, in the sam-

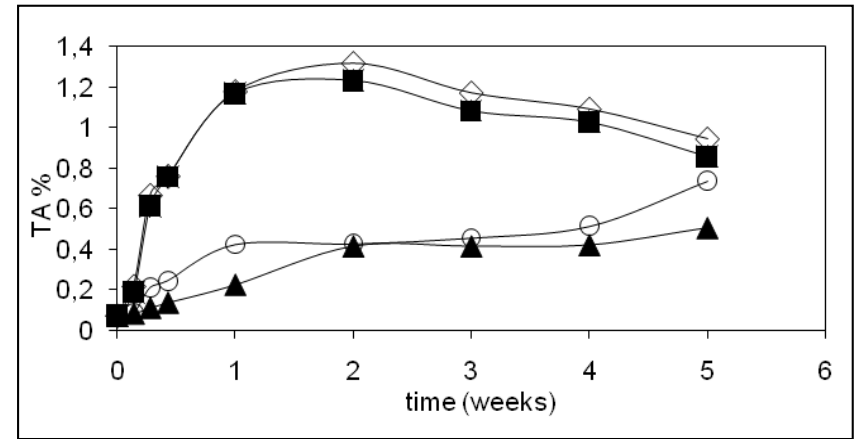

Fig. 4. Changes of TA in soymilk during the growth of L. casei in whole fermented soymilk; samples without ( $\mathbf{\square})$ and with $(\diamond)$ sorbitol stored at $25^{\circ} \mathrm{C}$; samples without $(\mathbf{\Delta})$ and with $(\mathrm{O})$ sorbitol stored at $4^{0} \mathrm{C}$.

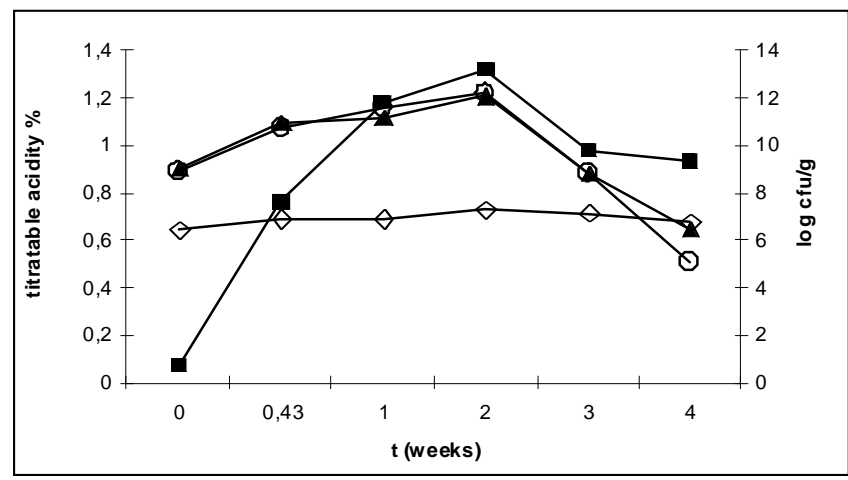

Fig. 5. TA $(\mathbf{\square}, \diamond)$ and growth $(\boldsymbol{\Lambda}, \bigcirc)$ of L. casei in freeze-dried fermented soymilk stored at $25^{\circ} \mathrm{C} ;(\mathbf{\square}, \mathbf{\Delta})$ samples without sorbitol; $(\diamond, \bigcirc)$ samples with sorbitol.

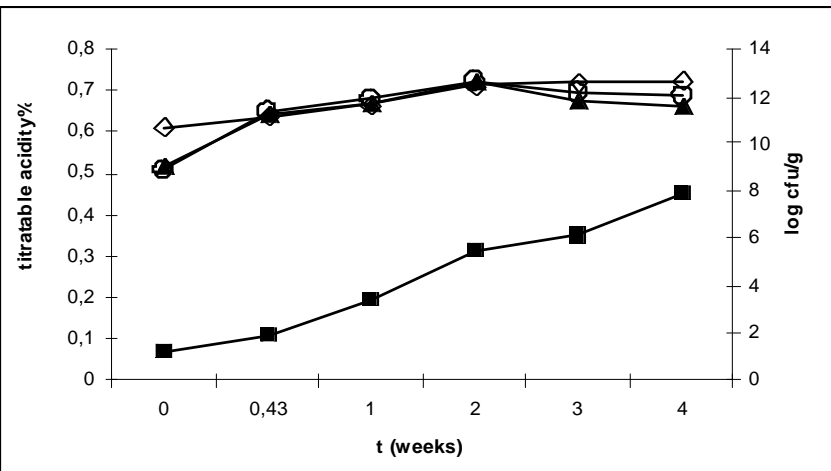

Fig. 6. TA $(\boldsymbol{\square}, \diamond)$ and growth $(\boldsymbol{\Lambda}, \bigcirc)$ of L. casei in freeze-dried fermented soymilk stored at $4^{0} \mathrm{C} ;(\mathbf{\square}, \mathbf{\Lambda})$ samples without sorbitol; $(\diamond, \bigcirc)$ samples with sorbitol.

ples without sorbitol, the population level was $9.7 \times 10^{8}$ cfu /ml ( $\sim 45 \%$ of survival), while in the samples with sorbitol, it was $3.1 \times 10^{9} \mathrm{cfu} / \mathrm{ml}$ ( $\approx 47 \%$ of survival).

Literature data (37) point out the factors affecting bacterial growth, including intrinsic factors, drying medium, storage and rehydration conditions, emphasizing the storage and rehydration temperature the most important. At low temperatures, bacterial metabolism is expected to decrease, including toxins' synthesis and resulting in increased viability. In order to determine the influence of drying medium, including sor- 


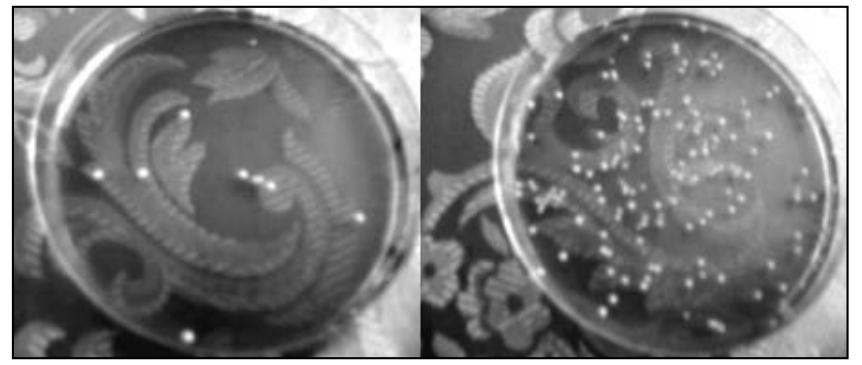

Fig. 7. Cell populations of $L$. casei in fermented dried soymilk estimated by the plate dilution method using MRS agar; (a) stored at $25^{\circ} \mathrm{C}$ and (b) stored at $4^{0} \mathrm{C}$.

bitol and storage temperature on probiotic growth, bacterial enumeration was performed in regular time intervals (the $1^{\text {st }}$ and the $3^{\text {rd }}$ day and once weekly during 5 weeks).

The presence of sorbitol increased viability of $L$. casei during freeze-drying and storage at both storage temperatures applied in the study. The maximum population was reached the second week, which can be considered as a period of exponential bacterial growth (52). During this period, the number of $\mathrm{cfu} / \mathrm{ml}$ in the freeze-dried fermented soymilk with sorbitol increased to $1.57 \times 10^{12} \mathrm{cfu} / \mathrm{ml}$ when stored at $25^{\circ} \mathrm{C}$ and to $4.83 \times 10^{12} \mathrm{cfu} / \mathrm{ml}$ when stored at $4^{\circ} \mathrm{C}$, while in the samples without sorbitol the population number increased to $1.08 \times 10^{12} \mathrm{cfu} / \mathrm{ml}$ and $4.5 \times 10^{12} \mathrm{cfu} / \mathrm{ml}$, respectively (Fig. 2-3; 5-6). In the next step of the study, no stationary phase of probiotic growth was observed in the samples stored at $25^{\circ} \mathrm{C}$ with and without sorbitol. Namely, constant decrease in the population level was observed; thus, at the end of the study the population level was $1.35 \times 10^{5}$ and 2.7 $\mathrm{x} 10^{6} \mathrm{cfu} / \mathrm{ml}$ in the samples without and with sorbitol, respectively. Considering the probiotic growth in the samples stored at $4^{\circ} \mathrm{C}$, a prolonged stationary phase was observed by the end of the study when the population number was $3.82 \times 10^{11} \mathrm{cfu} / \mathrm{ml}$ and $1.12 \times 10^{12} \mathrm{cfu} / \mathrm{ml}$ in the samples without and with sorbitol, respectively.

In order to determine the dominant factor affecting probiotic growth, two-factorial analysis of variance was applied to analyse data obtained from the viability examination studies. The statistical analysis confirmed that storage temperature dominantly influenced on the viability of L. casei in both samples with and without sorbitol $(p<0,05)$. The critical value of $\mathrm{F}$ for testing the dominant influence was 4.35 , while the test statistic values of the variance ratio were $5.76,0.81$ and 0.10 , respectively for the temperature, sorbitol and the interaction between process variables.

\subsubsection{Rehydration studies}

Rehydration is an important step in the recovery of probiotic from dried diary products. An organism which survives various steps, such as freezing, drying and storage may lose its viability during rehydration. Poor recovery of cells may be attributed to inadequate rehydration procedure. Yuksekdag et al. (53) indicated that rehydration temperatures between $15^{\circ} \mathrm{C}$ and $50^{\circ} \mathrm{C}$ were the best for $L$. casei, with the temperature of $37^{\circ} \mathrm{C}$ as the most convenient, while in the study of Prasad et al. (54), temperature of $45^{\circ} \mathrm{C}$ and exposure of $30 \mathrm{~min}$ was evaluated as the best for L. rhamnosus HN001 (subtype of $L$. casei). On the other hand, several investigators have reported that rehydration at the refrigeration temperature may cause leakage of intracellular substances from the cells, thereby resulting in low viability (51).

Table 1 . shows the effect of rehydration temperature on the recovery of $L$. casei from the dried fermented soymilk. The studies were performed in the second week when maximal probiotic growth was observed in the samples stored at $25^{\circ} \mathrm{C}$.

According to the results obtained one can conclude that there was higher recovery rate in the samples rehydrated at $45^{\circ} \mathrm{C}$, which can be considered as optimum rehydration temperature. These results confirm the positive effect of sorbitol on bacterial growth. Namely, at all rehydration temperatures studied, recovery was greater in the samples with sorbitol. The possible mechanisms underlying sorbitol protection of probiotic cells would be prevention of damage to the membrane via interaction therewith, prevention of lipid oxidation owing to its antioxidant properties, stabilisation of the protein structure, and hence preservation of functionality associated with formation of sorbitolprotein complexes (37).

\subsubsection{Acid challenge}

Results obtained for acid tolerance of $L$. casei in fermented soymilk are presented in Table 2. As one can see, the survival of $L$. casei was between 43.52 and $47.53 \%$ and it was higher in the samples with the sugar substrate in the growth medium with improvement in viability of approximately 1 log.

Results obtained for acid tolerance of $L$. casei in the freeze-dried soymilk after 1 week storage at $25^{\circ} \mathrm{C}$ and $4^{\circ} \mathrm{C}$ (Fig. 8) have revealed higher percents of survival in comparison with those in non-freeze dried soymilk samples with and without sorbitol. Namely, more than $65 \%$ of them survived this challenge with improvement in viability when sorbitol was added between 0.3 and 0.5 log depending on the storage temperature.

\section{Conclusion}

In conclusion, a stable probiotic diary product of dried fermented soymilk with $L$. casei was prepared in which the concentration of $L$. casei remained above therapeutic level of $10^{7}$ during the investigated storage period of 5 weeks and after acid challenge. Adding sorbitol in the growth medium 
Table 1. Effect of rehydration temperature on the recovery of $L$. casei from dried fermented soymilk.

\begin{tabular}{ccc}
\hline \hline $\begin{array}{c}\text { Rehydration } \\
\left({ }^{\circ} \mathrm{C}\right)\end{array}$ & $\begin{array}{c}\text { Population } \\
\text { of } \text { L. case } \text { in } \\
\text { dried fermented } \\
\text { soymilk without } \\
\text { sorbitol }(\mathrm{cfu} / \mathrm{ml})\end{array}$ & $\begin{array}{c}\text { Population } \\
\text { of } \begin{array}{c}\text { L. casei in } \\
\text { dried fermented } \\
\text { soymilk with } \\
\text { sorbitol }(\mathrm{cfu} / \mathrm{ml})\end{array}\end{array}$ \\
\hline $25^{\circ} \mathrm{C}$ & $1.08 \times 10^{12}$ & $1.57 \times 10^{12}$ \\
$45^{\circ} \mathrm{C}$ & $6.07 \times 10^{12}$ & $7.56 \times 10^{12}$ \\
$90^{\circ} \mathrm{C}$ & $9.00 \times 10^{5}$ & $1.73 \times 10^{6}$ \\
\hline
\end{tabular}

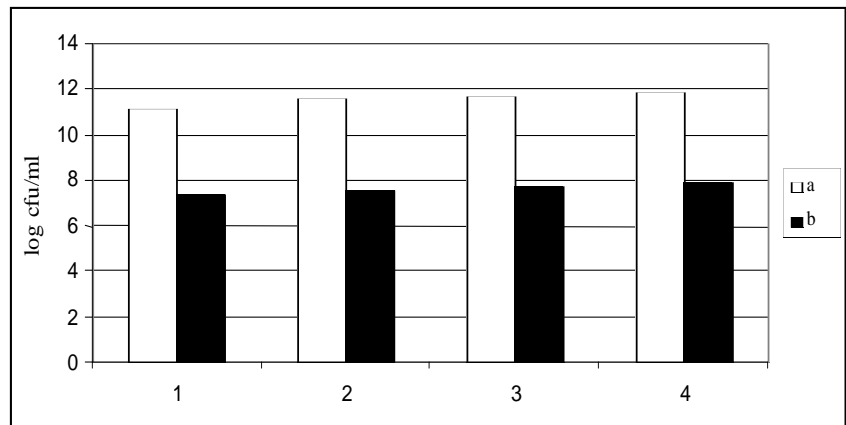

Fig. 8. Viability of L. casei in fermented freeze-dried soymilk after 1 week storage at $25^{0} \mathrm{C}$ (1: without and 2: with sorbitol) and $4^{0} \mathrm{C}$ (3: without and 4 : with sorbitol); a: no acid challenged and b: acid challenged samples.

increased survival rate of $L$. casei during fermentation, freeze-drying, rehydration and storage, and it significantly improved the protection of bacterial cells from acid stress injury. A higher percent of survival was also noted for $L$. casei when the dried fermented soymilk was stored at $4^{\circ} \mathrm{C}$ than at $25^{\circ} \mathrm{C}$. In order to administer higher therapeutic level of probiotic cells to, a rehydration temperature of $45^{\circ} \mathrm{C}$ is recommended.

\section{References}

1. P. McCue and K. Shetty, Crit. Rev. Food Sci. Nutr., 44, 361-367 (2004).

2. D. O. Otieno, H. Rose and N. P. Shah, Food Chem., 105, 1642-1651 (2006).

3. D. O. Otieno, J. F. Ashton and N. P. Shah, Int. J. Food Microbiol., 115, 79-88 (2007).

4. G. Rimbach, C. Boesch-Saadatmandi, J. Frank, D. Fuchs, U. Weenzel, H. Daqniel, W. L. Hall and P. D. Weinberg, Food and Chem. Toxicol., in press, (2007).

5. T. L. Dog, Am. J. Med., 118, 98-108 (2005) .

6. K. L. Fritz, C. M. Seppanen, M. S. Kurzer and A. S. Csallany, Nutr. Res., 23, 479-487 (2003).

7. Y-C. Wang, R. C. Yu and C. C. Chou, Food Microbiol., 23, 128-135 (2006).

8. J-S. Lee, Life Sci., 79, 1578-1584 (2006).

9. J. Cho, S. Ahn, J. Lee, W. Lee and K. Park, Eur. J. Pain, 10, S60 (2006).

10. F-H. Liao, M-J. Shieh, S-C. Yang, S-H. Lin and Y-W. Chien, Nutrition, 23, 551-556 (2007).

11. M. F. McCarty, Med. Hypotheses, 66, 1093-1114 (2006).
Table 2. Acid tolerance of $L$. casei in fermented soymilk.

\begin{tabular}{ccc}
\hline \hline Sample & $\begin{array}{c}\text { Viability of } \\
\text { L. casei in acid } \\
\text { non-challenged } \\
\text { sample } \\
(\mathrm{cfu} / \mathrm{ml})\end{array}$ & $\begin{array}{c}\text { Viability of } \\
\text { casei in acid } \\
\text { challenged } \\
\text { sample } \\
(\mathrm{cfu} / \mathrm{ml})\end{array}$ \\
\hline $\begin{array}{c}\text { Fermented soymilk } \\
\text { Fermented soymilk } \\
\text { with sorbitol }\end{array}$ & $9.7 \times 10^{19}$ & $5.0 \times 10^{8}$ \\
\hline
\end{tabular}

12. R. H. Knopp, R. Superko, M. Davidson, W. Insull, C. A. Dujovne, P. O. Kwiterovich, J.H. Zavoral, K. Graham, R. R. O`Connor and D. A. Edelman, Am. J Prev. Med. 17, 18-23 (1999).

13. Y-C. Wang, R. C. Yu and C. C. Chou, Food Microbiol., 19, 501-508 (2002).

14. Y-C. Wang, R. C. Yu, H. Y. Yang and C. C. Chou, Food Microbiol., 20, 333-338 (2003).

15. M. M. Brashears, D. Jaroni and J. Trimble, J. Food. Prot., 66, 355-363 (2003).

16. E. B. Minelli, A. Benini, M. Marzotto, A. Sbarbati, O. Ruzzenente, R. Ferrario, H. Hendriks and F. Dellaglio, Int. Diary J., 14, 723-736 (2004).

17. J. M. T. Hamilton-Miller, Int. J. Antimicrob. Agents, 22, 360-366 (2003).

18. W-H. Lin, C-F. Hwang, L-W. Chen and H-Y. Tsen, Food Microbiol., 23, 74-81 (2006).

19. O. N. Donkor, A. Henriksson, T. K. Singh, T. Vasiljevic and N. P. Shah, Int. Diary J., in press, (2007).

20. G. E. Perdigon, E. Vintini, S. Alvarez, M. Medina and M. Medici, J. Diary Sci., 82, 1108-1114 (1999).

21. C. A. Pedone, E. P. Arnaud, E. R. Postaire, C. F. Bouley and P. Reinert, Int. J. Clin. Prot., 54, 568-571 (2000).

22. H. Szajewska, M. Kotovska, J. Z. Mrukwicz, M. Armanska and W. Mikolajczyk, J. Pediatr., 138, 361-365 (2001).

23. R. Oozer, N. G. Fenillerat, A. Alpert, M. van de Guchte, J. Auba, J. Mengand and G. Gorthier, Appl. Environ. Microbiol., 68, 3570-3574 (2002).

24. A. Sullivan and C. E. Nord. J. Int. Med., 257, 78-92 (2005).

25. V. O. Oyetayo, F. C. Adetuyi and F. A. Akinyosoye, Af. J. Biotechnol., 2, 448-452 (2003).

26. N. M. de Roos and M. B. Katan, Am. J. Clin. Nutr., 71, 405-411 (2000).

27. T. Asahara, Antimicr. Agents Chemother., 45, 1751-1760 (2001).

28. D. Sgouras, P. Maragkoudakis, K. Petraki, B. MartinezGonzales, E. Erioton, S. Michopoulos, G. Kalantzopoulos, E. Tsakalidon and A. Mentis, Appl. Environ. Microbiol., 70, 518-526 (2004).

29. C. Dunne, L. O`Mahony, L. Murphy, G. Thornton, D. Morrissey, S. O`Halloran, M. Feeney, S. Flynn, G. Fitzgerald, C. Daly, B. Kiely, G. C. O`Sullivan, F. Shanahan and J. K. Collins, Am. J. Clin. Nutr., 73, 386-392 (2001).

30. B. Barcena, A. L. Ragout and P. R. Cordoba, Appl. Microbiol. Biotehnol., 51, 316-324 (1999).

31. M-T. Tien, S. E. Girardin, B. Regnault, L. Le Bourhis, M-A. Dillies, J-Y. Coppee, R-B. Sicard, P. J. Sansonetti and T. Pedron, J. Immunol., 176, 1228-1237 (2006).

32. K. Adhikari, A. Mustapha, J. U. Grun and L. Fernando, J. Diary Sci., 83, 1946-1951 (2000). 
33. A. Lorens-Hattingh and C. B. Viljeon, Int. Diary J., 11, 1-17 (2001).

34. N. P. Shah, in Encyclopedia of Diary Science, Academic press, London, 2002, pp 147-151.

35. A. Talwalkar and K. Kailasapathy, Compreh. Rev. Food Sci. Food Saf., 3, 117-124 (2004).

36. P. Capela, T. K. C. Hay and N. P. Shah, Food Res. Int., 39, 203-211 (2006)

37. A. S. Carvalho, J. Silva, P. Ho, P. Teixeira, F. X. Malcata and P. Gibbs, Int. Diary J., 14, 835-847 (2004).

38. T. D. Klingberg and B. B. Budde, Int. J. Food. Microbiol., 109, 157-159 (2006).

39. A. K. Anal and H. Singh, Trends Food Sci \& Technol., 18, 240-251 (2007).

40. G. Zarate and M. A. Nader-Macias, Proc. Biochem., 41, 1779-1785 (2006).

41. A. S. Carvalho, J. Silva, P. Ho, P. Teixeira, F. X. Malcata and P. Gibbs, Biotechnol. Lett., 24, 1587-1591 (2002).

42. A. S. Carvalho, J. Silva, P. Ho, P. Teixeira, F. X. Malcata and P. Gibbs, J. Appl. Microbiol., 94, 947-952 (2003a).

43. A. S. Carvalho, J. Silva, P. Ho, P. Teixeira, F. X. Malcata and P. Gibbs, Int. Diary J., 13, 463-468 (2003b).

44. A. S. Carvalho, J. Silva, P. Ho, P. Teixeira, F. X. Malcata and P. Gibbs, Le Lait, 83, 203-210 (2003c).
45. G. De Castro, H. Bredholt, A. R. Strom and A. Tunnacliffe, Appl. Environ. Microbiol., 66, 4142-4144 (2000).

46. AOAC. Official Methods of Analysis $14^{\text {th }} \mathrm{Ed}$. Washington, DC, Association of Official Analytical Chemists, 1984.

47. Leverrier, Y. Fremont, A. Rouault, P. Boyaval and G. Jan, Food Microbiol., 22, 11-18 (2005).

48. M-Y. Ha, S-W. Kim, Y-W. Lee and S-J. Kim, J. Biosci. Bioeng., 96, 134-140 (2003).

49. W. D. Wayne, Biostatistics: A foundation for analysis in the health sciences, $5^{\text {th }}$ Ed., John Wiley\&Sons, Inc, 1987, pp 310-327.

50. G. F. de Valdez, G. S. De Giori, A. P. De Ruiz Holgado and G. Oliver, Appl. Environ. Microbiol., 49, 413-415 (1985).

51. Y-C. Wang, R. C. Yu and C. C. Chou, Int. J. Food Microbiol., 93, 209-217 (2004).

52. K. Todar, Growth of bacterial population, Todar's Online Textbook of Bacteriology, (2002).

53. Z. N. Yuksekdag, Y. Beyath and B. Aslim, Nahrung/Food, 48, 218-220 (2004).

54. J. Prasad, P. McJarrow and P. Gopal, Appl. Environ. Microbiol., 69, 917-925 (2003).

\title{
Резиме
}

\section{Виталност на L. casei при ферментација во млеко од соја и во млеко од соја во прав; влијание на крипротектантот, рехидратацијата и температурата на чување}

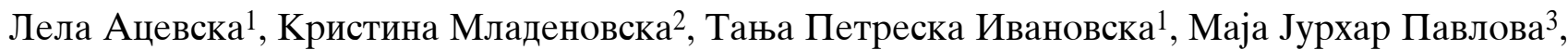 \\ Милена Петровска ${ }^{3}$, Ангела Делова ${ }^{4}$, Лидија Петрушевска Този ${ }^{*}$
}

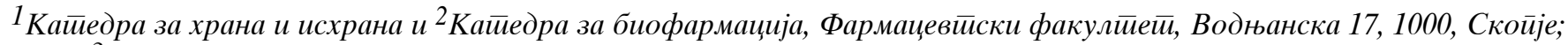

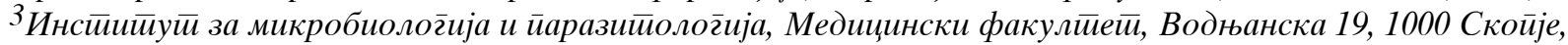 Универзииеей “Св. Кирил и Мейоди”, Скойје; Македонија;

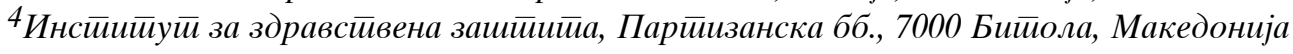

Клучни зборови: L. casei, ферментирано соја млеко, лиофилизација, сорбитол, виталност

Подготвен е стабилен пробиотски прехрамбен производ на соја млеко во прав со L. casei во кој терапевтската концентрација на пробиотикот опстојува над терапевтското ниво од $10^{7} \mathrm{cfu} / \mathrm{ml}$. Испитувана е виталноста на L. саsei и ефектот на сорбитол при ферментација на млекото од соја. На крајот од ферментацијата која се одвиваше 72 часа на температура од $25^{\circ} \mathrm{C}$ одредени се $\mathrm{pH}$ вредноста и титрациската киселост на млекото од соја и тие изнесуваа приближно 3.41 и $0.760 \%$. Млекото од соја го поддржува растот на $L$. саsei со подобрување на виталноста од $0.24 \log$ на крајот од ферментацијата кога во медиумот е додаден сорбитол. Испитуван е и ефектот на сорбитол врз подобрувањето на виталноста во текот на сушењето со лиофилизација, рехидратацијата и при чувањето во период од 5 недели под различни температурни услови. По сушењето, процентот на преживување на L. casei изнесува $46 \%$. Сорбитолот ја подобрува виталноста на $L$. casei за $0.51 \log$ веднаш по сушењето и за $1.30 \log$, односно $0.47 \log$ на крајот од 5-неделниот период кога се чува на $25^{\circ} \mathrm{C}$, односно $4^{\circ} \mathrm{C}$. Млекото од соја во прав, рехидрирано на $45^{\circ} \mathrm{C}$, е оптимално за размножување на $L$. casei со подобрување во виталноста од $0.68 \log$ кога во млекото е додаден сорбитол. Забележан е повисок процент на преживување на $L$. casei кога млекото од соја во прав се чува на температура од $4^{\circ} \mathrm{C}$ во однос на $25^{\circ} \mathrm{C}$, со подобрување на виталноста од $6 \log$ на крајот од 5 неделниот период на чување на примероците со и без сорбитол. Ферментираното млеко од соја во прав со сорбитол обезбедува висока толерантност на L. casei во симулирани услови на желудник со одржување на терапевтската концентрација над $10^{7} \mathrm{cfu} / \mathrm{ml}$. 